The International Journal of Social Sciences and Humanities Invention 7(01): 5790-5795, 2020

DOI: 10.18535/ijsshi/v7i01.02

ISSN: 2349-2031

(C) 2019, THEIJSSHI

Research Article

\title{
Synergy and optimization of Local institutional to Repair Gambir (Uncaria gambir Roxb) Market in Indonesia
}

\author{
${\text { Wedy } \text { Nasrul }^{1 *} \text {, Zulmardi }}^{2}$, Tri Irfa Indrayani ${ }^{3}$ \\ ${ }^{1}$ Agribusiness, Muhammadiyah University of West Sumatera, Padang, Indonesia \\ ${ }^{2}$ Forestry, Muhammadiyah University of West Sumatera, Padang, Indonesia \\ ${ }^{3}$ Management, Muhammadiyah University of West Sumatera, Padang, Indonesia
}

\begin{abstract}
The relation between institutions and synergy between social capital produce social capital performance. Relationship and synergy between social capital between institutions will produce the best collective action. Collective action formed able to solve a problem in and between the institutions. Research aim of looking at the a lot of synergy of local institutions, the performance of social capital are quoted on the gambir. So on as well will be canvassed to see the act of collectively that is formed to address the issues the market gambir. This research methodology used a quantitative approach. The kind of research is descriptive. This study using a case study in the agricultural gambir. Research methodology this used a quantitative approach.The kind of research is descriptive. The research uses strategy case study. A case study of agricultural market gambir (Uncaria Gambir Roxb). Enrichment data used method of qualitative. Forms used as, observation, interview, group discussions and documentation. Data analysis in depth uses the method inductive analysis and logical analysis. The analysis of the performance of social capital market gambir shows high social capital performance. High social capital performance on the gambir because the network high on bonding social capital and sinerji high on bridging social capital. High social capital performance produce collective action. Collective action happened transact on time and the same place between farmers and gambir gatherers in the market village. The transaction in time and place the same caused the price of more competitive because the competition among gambir gatherers. Social capital has also built the collective action for the repair of products and the sustainability of gambir farming.
\end{abstract}

Key words: social capital, agricultural market

\section{Introduction}

Social capital is part of the resources real or potential institutionalized and used effectively in accordance with the magnitude of the network. Social capital serves to capital hold so as to be mutually beneficial. Social capital be used as direct access to economy resources as individuals, subsidized loans recommendations and market investments are protected (Bourdieu, 1986).

The concept of social capital also to integrate the concept of the network and institutional (synergy perspective). The network is going on between the government and society for the principle of proximity. Relationships formed a purpose that is profitable in exchange (Woolcock, 2000). Social capital perspective synergy will contribute to the stronger collective action, maintained and complementary (Evans, 1996;
Meinzen - Dick et al, 2004). so as to the market can function properly. Market functioning well help ensure efficient allocation of resources and maximize welfare (Barrett and Emelly, 2005; Eaton dan Meijerink, 2007).

However, many agricultural markets in rural areas are not functioning properly and are detrimental to farmers. Markets that do not function well and are detrimental to farmers are also experienced by the gambir market farming. The reason is the low bargaining position of farmers, monopsony market structure, prices are not integrated with export prices, the market is controlled by gatherers (toke) and access to closed information (Afrizal, 2009; Sa'id, 2011; Nasrul, 2016). This condition is exacerbated by the habit of farmers mixing gambir so as to make quality 
lower, mixing gambir is left to gatherers to reduce prices in the market (Afrizal, 2009; Sa'id, 2011).

The above description shows that the importance of the performance of social capital from institutional synergy to solve gambir market problems. The musty contribution of aspects of social capital (Coleman, 2009) and the synergy of social capital (Woolcock, 2001) contribute to collective action that is stronger, safeguarded and complementary (Evans, 1996; Meinzen-Dick et al, 2004). The purpose of this study looks at the synergy of local institutions, the performance of social capital in the gambir market. Then we will also see collective action that is formed to solve the gambir market problem.

\section{Methods}

This research method uses a quantitative approach. This type of research is descriptive with a case study design. Case studies were carried out at the gambir (Uncaria Gambir Roxb) agricultural market. Gambir agricultural market is located in the Lubuak Alai Village (Nagari), Kapur IX District. Lima Puluh Kota Regency of West Sumatra Province, Indonesia.

For data enrichment used qualitative methods or techniques such as observation, interviews, group discussions, and documentation (Creswell, 2002). In-depth data analysis uses inductive analysis and logical analysis methods that contain data reduction and interpretation elements (Marshall and Rossman, 1989). Analysis of the performance of social capital is done by analyzing four social network models by Woolcock (1998). Explanation of Woolcock, a synergy of top down social networks (bridging and linking social capital) interacting with bottom up social networks (bonding social capital), yields 16 different performance possibilities. High performance is called beneficient autonomy, low performance is called anarchic individualism.

\section{Results}

The performance of social capital is the result of discussion of relations analysis and the synergy of social capital from the network and the interaction of the lower group (bounding social capital) with the network and the interaction of the upper group (bridging social capital and linking social capital). High social capital performance is called "beneficent autonomy" while the worst or low performance is called "anarchic individualism" (Woolcock 1998; 2001). The performance of social capital in producing collective action is explained through the analysis of relations and synergy of social capital in local institutions involved in the gambir market. Furthermore, the results of the performance of social capital formed in each gambir market are determined.

\section{Relationships and Social Capital Synergy}

Woolcock Analysis (2001) three forms of social capital (bonding social capital, bridging social capital and linking social capital) will be explained in this section. Social capital will refer to social forces developed by individuals or groups in establishing relationships. This social power is developed to maintain life through a process of limited interaction with a community (bonding social capital) and interaction with networks outside the community at the mezzo and macro level (bridging social capital and linking social capital).

Looking at Woolcock's (2001) analysis of social capital, the relationships and synergies of social capital formed between local institutions supporting the gambir market, consist; a) bonding social capital is social capital anchored to farmer institutions. Seeing integration in institutions and the level of outreach of farmers institutions have the same ability; b) bridging social capital is social capital that is tied to the gatherers institution. Seeing the integration in institutions and the level of synergy reach with other institutions has more capabilities, and c) linking social capital which is social capital that is tied to government institutions and customary institutions. See the level of integrity and reach of synergy with other institutions, have better abilities and can also provide support and other facilities.

\section{Social Capital Performance}

Institutions in the gambir market consist of farmers, gatherers, government institutions and customary institutions. Gambir farmer institutionalization is informal. Farmer organization was formed for the production process on the gambir land (manggampo). Institutional farmers formed an agreement between landowners and workers on gambir land. Gambir farmer working groups are formed 
informally with as many as three to five people. The number of farmer institutions reaches around 300 in the Lubuak Alai Village.

\section{- Bonding social capital}

Analysis of bonding social capital in farmer institutions shows that integration and network of farmer institutions have moderate indicators on the gambir market. The similarity and kinship within the work group creates an attitude of mutual trust, sympathy and cooperation between them. However, the working groups in the gambir field also generally have weaknesses. Their weaknesses such as lack of capital and the inability to access other gatherers outside their territory. Farmer groups working in the gambir field are also still informal in nature, so the level of utilization of groups is only as needed. Farmers who own small plots of land are very dependent on gatherers to borrow money and markets to sell their produce.

Networks at the level of bonding social capital also have moderate performance, because network indications on bonding social capital with other institutions are still lacking, even if there is only the village government and customary institutions (Kerapatan Adat Nagari/KAN). Networking with formal financial institutions and higher local government was not formed, so gambir farmer working groups did not receive much program and assistance from the local government. However, a good relationship or network on institutions in the gambir market, gives an influence with the transaction being reacted at the same time and place in the market village. Joint sales and transactions make the market more competitive, because there is competition between gatherers to get gambir from gatherers.

\section{- Bridging social capital}

Furthermore, it can be seen an analysis of the performance of social capital at the level of bridging social capital in market gambir. Integration and synergy gatherers (bridging social capital) in the gambir market has high indications. High integration because the indicators at the level of bridging social capital have good and useful traits. Sinerji at the bridging social capital level also has high performance.
The sustainability of gambir cultivation and markets is very important. Looking at the social relations of institutions involved in it, the role of gatherers institutional is very important for the sustainability of gambir cultivation. Analysis of social capital at the mezzo level (bonding) shows the role of gatherers (toke) important for the sustainability of gambir production and markets. In addition to buyers of gambir farmers, gatherers also function as a place to borrow money for farmers. The loan is used by farmers for gambir cultivation and household needs. Farmer loans to gatherers range from $\mathrm{Rp} .2,000,000$ up to $\mathrm{Rp}$ $5,000,0000$ for one production process. The production process lasts for 4 months for an area of 2 hectares.

Gatherers institutional in Lubuak Alai Village consists of large gatherers (toke gadang) and small gatherers (toke tangah hari). The number of gatherers in Lubuak Alai Village is currently 15 people, 3 large gatherers, the remaining 12 small gatherers. The number of small gatherers is usually based on the price of gambir. When cheap gambir prices usually appear small gatherers, because their capital is not much to be a gatherers. Gambir prices from April to June 2019 range from Rp. 24,000 up to 35,000 one kilogram. Gambir prices have reached Rp 120,000, - one kilogram. Large gatherers and small gatherers are largely unrelated. Large gatherers who are not related will compete in establishing cooperation with farmers. The cooperation network was formed by farmers and gatherers to get a place to sell gambir products. Farmers choose gatherers who provide high prices, as a relationship. Intense competition among fellow gatherers, makes gatherers maintain cooperation with farmers with various strategies. The strategy is often done is to provide large and old loans. Large and long-term loans make cooperation and engagement between farmers and gatherers even more sustainable.

The financial capacities of large gatherers and small gatherers are also different. Large gatherers have a business capital of Rp. $300,000,000$ to Rp. 500,000,000 every week, with the number of gambir collected reaching approximately 8 tons. Small gatherers have a maximum capital of Rp. 75,000,000 every week, with the maximum amount of gambir collected around 3 tons per week. This capital capability 
also influences the level of competition between large gatherers and small gatherers. Even if there is a small gatherers that is liked by farmers, but because of limited capital ability can no longer buy gambir farmer. The results of gambir gatherers are forwarded to exporters in Padang, Medan and Jakarta. The relationship between large gatherers and exporters is very good. They do not have formal employment contracts, only based on mutual trust. If there are problems and changes in agreements are usually discussed in friendship or family terms. The deal that was built related to gambir prices every week.

Bridging social capital analysis of gatherers institutional is seen in large gatherers and small gatherers. Gambir market institutions have formal and informal rules. Formal rules are formed by the village administration with customary institutions. Formal rules are agreed upon by all actors who transact in the gambir market. The village government has little contact with farmers. The village government will facilitate farmers usually with the district and district governments if there are programs and activities related to gambir farmers. The village government usually also provides administrative assistance to farmers if there is a program from the district or district government. The Lubuak Alai Village does not have a formal financial institution for farmers. There is not so much the role of the village government to provide access to special financial institutions for gambir agriculture. If there is a relationship between farmers and financial institutions, usually for motor vehicle loans. The village government facilitated farmers with financial institutions for the motor vehicle credit requirements.

The level of synergy of bonding social capital that is being owned by farmer institutions. Social power based on closeness is developed to maintain life so that bonding social capital can function less optimally (Woolcock, 2001). The typology of bridging social capital tied to large gatherers has high integration. Bridging social capital high performance on gatherers is due to the ability and good mastery of capital by large gatherers. Large gatherers have large capital, marketing skills and good cooperation with exporters. His long experience as a gatherers and the average large gatherers is that gambir farmers have previously strengthened the capacity of large gatherers in gambir market institutions. Adequate capital occurs due to the mastery of a number of capital, both physical, economic, and social capital (integration, network and synergy) and knowledge (Bourdieu, 1986; Woolcock, 1998).

\section{- Linking social capital}

High performance of linking social capital through the role of the village government together with customary institutions in managing the gambir market. Village governments and customary institutions make rules for farmers and gatherers to transact. Gambir gatherers and gambir farmers conduct transactions at the same time and place. Transactions are done on Sundays at the gambir kiosk. Gambir kiosk is located in the village market. Benefits for farmers with transactions at the same time and place make prices more competitive. Price competition between gatherers can reach Rp. 2,000 one kilogram, farmers' production during the week between $100 \mathrm{~kg}$ to $200 \mathrm{~kg}$. While the benefits for gatherers easily collect farmers loans. During this time, cheating farmers sometimes sell their gambir not to gatherers who provide loans. In addition, the village government and customary institutions also collect taxes (natura). The results of tax collection are used for village development. Agreements on market management, joint transactions and tax collection and tax use are made in the Village Regulation (PERNA). The case in Hungary, the synergy between the regional government, the central government (the agriculture department) and wine producers. To improve the regional economy, the local government connects farmers and wine producers with the agriculture department in developing processing facilities and loan subsidies to buy a champagne factory. Local government policy, helping petni do joint marketing. The aim is to stabilize prices and business that is conducive (Megyesi et al, 2010).

\section{Conclutions}

The performance of social capital and institutional synergy is seen from the relations and networks of social capital. The performance of social capital is summarized from the total performance of bonding networks and synergy linking (Woolcock, 2001). The results of the analysis of the social capital market performance 
of gambir shows high social capital performance. The high performance of social capital in the gambir market shows a high level of networking in bonding social capital and high synergy in bridging social capital, so the results of the analysis obtain high social capital performance in the gambir market. The high performance of social capital influences the synergy between institutions involved in the gambir market to produce collective action. The resulting collective actions are useful for fixing the problems of the gambir market.

Collective action from institutional synergy can make the gambir market more competitive (perfect competition). Collective action that is formed can simplify the transaction process of resolving the problems of actors who transact in the gambir market. Collective action also helps the sustainability of gambier farming in Lubuak Alai Village. The constitution is in accordance with the opinion (Olson, 1971) where collective action occurs if there are benefits derived from the collaboration process. Collective action will facilitate and expedite the parties to the transaction (Meinzen - Dick et al, 2004; Syahyuti, 2008). The values of social capital that are built such as trust and cooperation also build collective action to improve the quality and quality of gambir products and the sustainability of gambir farming. The findings of $\mathrm{Fu}$ et. al (2018) togetherness values become the basis of companies and farmers to improve product quality.

\section{Acknowledgments}

Authors thanks to the 2019 Research Grant (PDUPT-Penelitian Dasar Unggulan Perguruan Tinggi) from the Ministry of Reseach and Higher Education, Republic of Indonesia for a generous financial support for conducting this research.

\section{References}

1. Afrizal, R. (2009). Analysis of Gambir Production and Marketing in Kabupaten Lima Puluh Kota West Sumatera Province. IPB Bogor.

2. Barrett and Emelly.( 2005). Agricultural markets in developing countries. The New Palgrave Dictionary of Economics, 2nd Edition. Cornell University
3. Bordieu, P. (1986). The Forms of Capital. Handbook of Theory of Research for the Sosiology of Education. Greendword Press.

4. Creswell, John W., (2002). Research Design; Qualitative \& Quantitative Approaches, Penerbit KIK Press, Jakarta.

5. Coleman, J.S. (2009). Social Capital in the Creation of Human Capital. The American Journal of Sociology, Vol. 94. 95-120.

6. Eaton and Meijerink. (2007). Markets, institutional change and the new agenda for agriculture. Markets, Chains and Sustainable Development Strategy and Policy Paper, No.6. Stichting DLO: Wageningen.

7. Evans and Boyte, (1989). Reviews the book "Free Spaces: The Sources of Democratic Change in America. Journal of American History; Mar 1989, Vol. 75 Issue 4. 1283-1284.

8. Fu, S. Liu, H. Tan, K.H, Zhan, Y, Ding, Y and Qi, W. (2018). How Social Capital Affects the Quality Performance of Agricultural Products: Evidence from a Binary Perspective of China Sustainability 2018, 10.1-15.

9. Marshall, C and Rossman, G.B. (1989). Designing Qualitative Research. Sage Publications.

10. Meinzen D.R, Di G.M, Carthy M.N. (2004). Methods for studying collective action in rural development. Agric Syst 82(3):197-214

11. Nasrul, W. (2016). Collective Action in The Market Gambir (Uncaria gambir Roxb) Through Local Institutions Nagari Lubuak Alai, Nagari Manggilang, Nagari Maek in Lima Puluh Kota District. Andalas University of Padang.

12. Olson, M. (1971). The Logic of Collective Action. Volume CXXIV. Harvard University Press, Cambridge.

13. Sa'id, G. (2011). Review of Agroindustrial Strategic Studies, Reasearches and Development in Indonesua: The Case of Oil Palm, Cacao and Gambir. J. Tek. Ind. Pert. Vol. 19(1), 2011.45-55.

14. Woolcock, M. (1998). Social Capital and Economic Development: Toward a Theoretical Synthesis and Policy 
Wedy Nasrul et. al/ Synergy and optimization of Local institutional to Repair Gambir (Uncaria gambir Roxb) Market in Indonesia

Framework. Theory and Society 27(2): 151-208

15. Woolcock, M and Narayan, P. 2000. Social Capital: Implications for evelopment Theory, Research, and Policy. Final version submitted to the World Bank Research Observer. Published in Vol. 15(2).

16. Woolcock, M. (2001). The Place of Social Capital in Understanding Social and Economic Outcomes. ISUMA Canadian Jousnal of Policy Reseach, Vol 2 (1), 1117. 